\title{
UTILIZATION OF SMARTPHONE DEVICES AND USE OF SOCIAL MEDIA IN NORTH MALUKU
}

\author{
Bahrawi \\ Balai Besar Pengembangan Sumber Daya Manusia dan Penelitian Komunikasi dan Informatika \\ (BBPSDMP Kominfo) Makassar, Indonesia \\ bahrawi@kominfo.go.id
}

\begin{abstract}
Basic guidelines. This document is itself an example of the desired layout (inclusive of this abstract) and can be used as a template. It contains information regarding desktop publishing format, type sizes, and typefaces. Style rules are provided that explains how to handle equations, units, figures, tables, abbreviations, and acronyms. Sections are also devoted to the preparation of acknowledgments, references, and authors' biographies. The abstract is limited to 150-200 words and cannot contain equations, figures, tables, or references. It should concisely state what was done, how it was done, principal results, and their significance.
\end{abstract}

Keywords: Utilization of Social Media; Smartphones; Technology Devices.

\section{INTRODUCTION}

The internet is one form of ICT that is now increasingly widely used by the global community. The research conducted by Kominfo in 2016 "Survey of Access and Use of ICTs by Households and Individuals in Indonesia" shows that National ICT development indicators continue to increase year by year. Household access to the internet has been increased to $36 \%$. It has changed the way people communicate [1]. By having an email address, people can follow various communication models on the internet such as forums, mailing lists or groups, social media, blogs, file sharing sites, etc.

It cannot be denied that Information and Communication Technology (ICT) has developed very rapidly, and has even revolutionized the human way of life, both towards ways communicate, learn, work, and so on. In this era, information and communication giving a huge space to organize all activities to be better, more accurate, instant, timely, comfortable and innovative. All of this is due to the transforming ICT all physical and static work processes become digital, mobile, virtual and personal. The role of ICT too penetrate into all sectors both social, economic, trade, education and even defense security.

ICT plays the role as enabler technology, if it is applied and used appropriately. It is very important for countries that are moving towards a knowledge-based society. By the increasing availability of information for the community, including those in rural areas, opportunities for people to develop independently by utilizing the internet for positive activities are increasingly open. However, internet availability also opens up opportunities for negative activities, such as social interaction, pornography, cyber fraud or crime, the doctrine of terrorism or extremist groups, etc [2].

Therefore, the problem formulation of current research is "how is the general description of the use and utilization of ICTs and social media?" This study aims to get an overview of the use of ICT and the use of social media in the North Maluku community. It focuses on the scope of ICT users with indicators of frequency of use, duration, purpose, activity, place of use, etc. According to Alter, ICT includes hardware and software those are utilized to carry out one or a number of data processing tasks, such as capturing, transmitting, storing, retrieving, manipulating, or displaying data [3].

According to the Ministry of Research and Technology, ICTs are part of science and technology related to the collection, acquisition, processing, storage, dissemination and presentation of information. Included in this definition are all hardware, software, content, and computer and telecommunications infrastructure. According to [4], ICT is a medium or tool for obtaining knowledge between people.

ICT covers two aspects: information technology and communication technology.

Information technology includes all things related to the process, the use as a tool, the manipulation, and the management of information, while communication technology is everything related to the use of tools to process and transfer data inter-device. It is why ICT can be interpreted as all activities related to the process, the manipulation, the management, and the transfer of information inter-media. ICT has played an important role that is inevitable in people's lives. ICT has entered all sides of life. Its application is expected to be able to increase productivity. The implementation of ICT might be seen in fields of :

1. Education. ICT has helped a lot in the process of optimizing teaching and learning. The teaching and learning system that used to seem boring and monotonous can be more interesting with the support of the use of ICTs, such as audio-visual equipment (multimedia-based). In addition, with the existence of ICT, students not only can get knowledge from the teacher but also can be through online media using the Internet network. E-learning as a further application of ICT in the world of education helps teachers or lecturers to be able to deliver material more flexibly without having to meet face to face with students. Likewise when sending assignments and dividing the subject matter, 
simply uploading and downloading the material via the Internet can immediately be accepted or used.

2. Health. We have seen many ICTs in the medical or health world. For example, when registering at a hospital, officers will serve using computer assistance. ICT makes it easy for the hospital to serve several people with only a very short time. Just imagine if at one time there were dozens of people who registered while the registration system was still manual, it would take a long time to be able to serve everyone. ICT in the medical world also began to be used in the form of database systems and medical devices. Various health examination equipment emerged as a result of the development of information and communication technology, such as Computer Tomography (CT) Scan which was used to examine the condition of the patient's body. Patient examination results can also be identified through medical records that have been stored in the form of electronic databases so that they can be found quickly when the doctor or patient concerned wants to see them. Not only that, ICT also began to be combined with artificial intelligence (AI) which produced expert systems. One of the current expert systems is Mycin which is used to help a medical interpreter diagnose blood diseases that are fast infectious and can then provide advice in the form of appropriate use. According to Horn, this system was implemented at Stanford Medical Center since 1979 [5].

3. Banking Sector. The application of ICT that is highly developed in the banking world is electronic banking or better known as e-banking. E-banking services that utilize the Internet network are very helpful for customers to be able to conduct banking transactions. Bank customers who do not have enough time to go to the bank to transfer funds, by the use of ICT, simply by typing SMS, the transfer of funds can be done easily. Likewise with cash withdrawals, the banks locations those are sometimes far from the reach of the customers, making it difficult for them to withdraw cash, but by the existence of an Automated Teller Machine (ATM) that is spread more than the number of banks, they can withdraw cash more easily without having to go directly to the bank. By this service, customers are increasingly treated and satisfied so that loyalty to the bank can be maintained.

4. Government Affairs. In this field, the application of ICT can be seen by the existance of governmental websites which are better known as electronic government or e-govt. Through the sites, the community can get to know more about the system of government where they in. Some websites also provide online discussion medias, where the public can discuss with the local government through the media. Policies, governmental structures, even the history can be obtained from the sites.

5. Police Sector. Making a Driving License (DL) is one of the activities that utilize ICT. By using a computer, digital camera, and fingerprint recorder, DL making and printing can be done quickly. Image compression technology that is used to do electronic fingerprint recording with a very small size making it not too wasteful of storage media. By using this fingerprint database storage technology, the process of fingerprint matching for certain cases, such as the comparison between suspect fingerprints and actual criminals can be done easily and quickly. Likewise with face recognition that can do the matching by looking at facial characteristics. The Police Department in California uses a database called the Law Enforcement Automated Data System (LEADS) to track former prisoners by matching them quickly with photos of suspects [6].

In addition to a number of fields that have been mentioned, there are still many ICT applications in life, including in the fields of trade and industry, such as the emersion of ecommerce systems and the product designing like Computer Aided Three Dimensional Interactive Application (CATIA) software that is used to realize car design and components, even for testing. This software is used by Dodge and Daimler Chrysler companies.

The United Nation E-Government Survey in 2010 showed that according to the E-Government Index ranking which contained indicators of online services, telecommunications infrastructure and human capital, Indonesia was ranked 109th out of 183 countries. Indonesia's position again under Singapore (11), Malaysia (32), Philippines (78) and Vietnam (90) [7].

Hanif Hoesin and Baso Saleh in 2007 conducted research on the Use of Computers and the Internet in Indonesia. The results showed that in terms of the ownership, the use of computers, as well as the Internet media utilization, were still equally low, even if the public appreciation of the new media is generally positive [8].

Wahyudiono in 2007 conducted research on ICT User Profiles in Surabaya. The results showed that the higher the level of education was, the more computer ownership and Internet use. Internet users are mostly young. The higher the age was, the fewer people use the Internet. The growth of Internet users is quite rapid, which is 6.5 percent within a period of six months. Most respondents use the internet at an internet cafe with intensity of usage once a week or twice. The number of internet users in the office is quite large with more frequent usage intensity, which is almost every day [9].

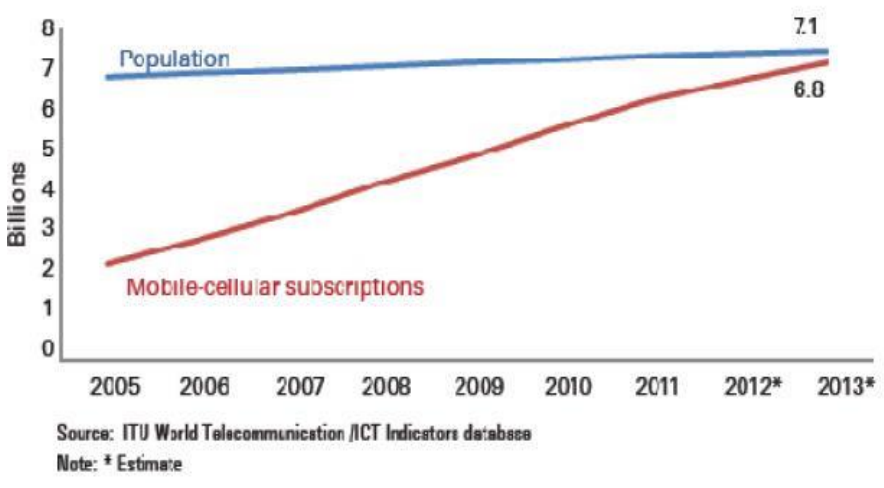

Fig. 1 Comparison of Population Growth and Mobile Cellular [10]

The development of telecommunications in Indonesia has entered a new phase with increasingly rapidly growing information technology industry. The reach of cellular phones 
has reached all Provinces in Indonesia and some Regencies / Cities in Indonesia. Telecommunication providers too more and more along with the types of telecommunications services provided starting from the telephone cable, or wireless, cellphone, and so on. Cellular communication is also not only voice communication, but also extends to data communication. Fig. 1 presented growth data mobile cellular with the increasing number of population, as well as the global development of ICT growth.

\section{METHOD}

In general, the method used in the current research is a survey with a quantitative approach. Primary data collection is carried out through surveys, while secondary data is collected through scientific search on the internet. Data collection methods used include: (1) secondary data collection from various sources, and processing. (2) primary data collection and processing. Data is the result of survey activities and also interviews with informants at the research location.

The survey method was a direct survey to households and individuals to conduct face-to-face interviews with respondents using questionnaires. The basis for this face-to-face interview was considered that the interviewer can approach the respondent personally to explain each question in the questionnaire so that the interview can take place smoothly, and the interviewer to be able to see the respondent's reaction directly to find out the level of honesty of the respondents in order to reduce the response bias. In addition to distributing questionnaires, primary data in the field was also collected in the form of in-depth interviews with several informants on site.

\section{A. Data Collection}

Data collection was carried out through direct interviews (face-to-face interview) of individual respondents in the household using a questionnaire instrument. Interviews are conducted in their nature domiciles.

The method of obtaining respondents is as follows: In each selected village, randomly select 2 Neighborhood Associations (RT). Both of RT units were chosen based on the dominant economic status. The first RT was chosen as representation of the middle-up society, while the second was chosen as representation of the middle-low society. For villages in the countryside, the first RT was the closer to the village center, while the second was vice versa. To determine these, researchers obtained information from the village head office.

In each selected RT, 8 households will be chosen with systematics sampling. Sampling is done by using a list of existing households. if there is no, then the listing is done on the spot. Furthermore, in each sample household, 1 respondent who fulfilled the requirements was chosen again using a random "Kish Grid" table.

The stages of conducting the survey are as follows:

1. The questionnaire sheet that has been filled in by the respondent is validated by the field coordinator to check the completeness of the respondent's answer, the truth of the respondent's existence and the interview process.

2. This validation is the first filter on the questionnaire. If the questionnaire sheet is declared invalid, then a re-interview process is conducted with new respondents (substitute respondents).

3. The final result of the field survey activity is a questionnaire sheet that has been filled in by the respondent and has passed the validation process.

In each selected district in North Maluku Province, 4 villages were randomly selected taking into account the representation of rural-urban strata. from the selected villages, 2 RTs were chosen again with rich or poor considerations, or far or near from the village center. At each RT chosen, then randomly selected 8 households using systematic sampling technique. So that each village is represented by 16 households.

TABLE 1

Kish Grid Matrix

\begin{tabular}{|c|c|c|c|c|c|c|c|c|c|c|c|}
\hline \multirow[t]{2}{*}{ No. } & \multicolumn{3}{|c|}{$\begin{array}{c}\text { Household } \\
\text { member who lives } \\
\text { here } \\
\end{array}$} & \multicolumn{8}{|c|}{ Household no.- } \\
\hline & Gen & & Age & 1 & 2 & 3 & 4 & 5 & 6 & 7 & 8 \\
\hline 1 & $\bar{M}$ & $\mathrm{~F}$ & & 1 & 1 & 1 & 1 & 1 & 1 & 1 & 1 \\
\hline 2 & $\bar{M}$ & $\mathrm{~F}$ & & 1 & 2 & 1 & 2 & 1 & 2 & 1 & 2 \\
\hline 3 & $\mathrm{M}$ & $\mathrm{F}$ & & 1 & 2 & 3 & 1 & 2 & 3 & 1 & 2 \\
\hline 4 & $\bar{M}$ & $\mathrm{~F}$ & & 1 & 2 & 3 & 4 & 1 & 2 & 3 & $\overline{4}$ \\
\hline 5 & $\mathrm{M}$ & $\mathrm{F}$ & & 1 & 2 & 3 & 4 & 5 & 3 & 4 & 5 \\
\hline 6 & $\mathrm{M}$ & $\mathrm{F}$ & & 1 & 2 & 3 & 4 & 5 & 6 & 3 & 6 \\
\hline 7 & $\bar{M}$ & $\mathrm{~F}$ & & 1 & 2 & 3 & 4 & 5 & 6 & 7 & 4 \\
\hline 8 & $\mathrm{M}$ & $\mathrm{F}$ & & 1 & 2 & 3 & 4 & 5 & 6 & 7 & 8 \\
\hline 9 & $\bar{M}$ & $\mathrm{~F}$ & & 1 & 2 & 3 & 4 & 5 & 6 & 7 & 8 \\
\hline 10 & $\bar{M}$ & $\mathrm{~F}$ & & 1 & 2 & 3 & 4 & 5 & 6 & 7 & 8 \\
\hline
\end{tabular}

The location of the object of this study which was sampled was the province of North Maluku, which consisted of several sub-village villages in the city/district in the province. Table 2 is a list of villages, sub-districts and cities/districts that were made in this study.

Shown in the Table 2 that the study sample consisted of 12 villages scattered in the province of North Maluku. these villages are Wailukum, Gotowasi, Wayamli, Cemara Jaya, Tawa Bacan Timur, Tomori, Babang, Mandoang, Toboko, Maliaro, Jambula and Toboleu.

\section{B. Success Risk Factors}

Succses and risk factors for this research are:

1. Risk factors: lies in the level of participation of respondents / data sources, remembering The respondent is widespread in all parts of Indonesia. To anticipate this condition, then cooperation with agencies that have authority and experienced in managing data in their respective fields (Director General of PPI, Director General of SDPPI, BKPM, BPS, Directorate General of Dikti, etc.).

2. Another risk factor is the accuracy of the estimated costs needed to conduct a survey. In carrying out activities, a 
decision may have to be made to limit the sector will be surveyed. As a guideline for determining options, the priority of the sector will be determined surveyed.

TABLE 2.

Sample Zones

\begin{tabular}{c|c|c|c}
\hline Provinsi & Kota/kab & Kecamatan & Desa \\
\hline Maluku utara & $\begin{array}{c}\text { Halmahera } \\
\text { timur }\end{array}$ & Kota maba & Wailukum \\
\hline Maluku utara & $\begin{array}{c}\text { Halmahera } \\
\text { timur }\end{array}$ & Maba selatan & Gotowasi \\
\hline Maluku utara & $\begin{array}{c}\text { Halmahera } \\
\text { timur }\end{array}$ & Maba tengah & Wayamli \\
\hline Maluku utara & $\begin{array}{c}\text { Halmahera } \\
\text { timur }\end{array}$ & Wasile & Cemara jaya \\
\hline Maluku utara & $\begin{array}{c}\text { Halmahera } \\
\text { selatan }\end{array}$ & $\begin{array}{c}\text { Bacan timur } \\
\text { tengah }\end{array}$ & $\begin{array}{c}\text { Tawa bacan } \\
\text { timur }\end{array}$ \\
\hline Maluku utara & $\begin{array}{c}\text { Halmahera } \\
\text { selatan }\end{array}$ & Bacan & Tomori \\
\hline Maluku utara & $\begin{array}{c}\text { Halmahera } \\
\text { selatan }\end{array}$ & Bacan timur & Babang \\
\hline Maluku utara & $\begin{array}{c}\text { Halmahera } \\
\text { selatan }\end{array}$ & Bacan selatan & Mandaong \\
\hline Maluku utara & Ternate & Ternate selatan & Toboko \\
\hline Maluku utara & Ternate & Ternate tengah & Maliaro \\
\hline Maluku utara & Ternate & Pulau ternate & Jambula \\
\hline Maluku utara & Ternate & Ternate utara & Toboleu \\
\hline
\end{tabular}

\section{RESULT AND DISCUSSION}

\section{A. Individual ownership of smartphones}

Smartphones are a very popular communication device today. The benefits that are not just for telephoning and SMS make it very popular with the public. Table 3 show the results of a survey related to ownership of smartphone devices in North Maluku. It can be seen that of the three districts those were sampled, it was the highest percentage of smartphone ownership in South Halmahera Regency: $44.74 \%$, then in Ternate City: $38.16 \%$ and the last was $17.11 \%$ in East Halmahera Regency.

TABLE 3

Ownership of a Smartphone

\begin{tabular}{c|c}
\hline Kota/kab & $\begin{array}{c}\text { Persentase } \\
\text { Kepemilikan }\end{array}$ \\
\hline Halmahera Timur & $17.11 \%$ \\
\hline Halmahera Selatan & $44.74 \%$ \\
\hline Ternate & $38.16 \%$ \\
\hline
\end{tabular}

Then in Table 4, we can see the percentage of smartphone ownership based on individual characteristics. It can be seen that most smartphone users are in urban areas, and from the middle class and those with high school education.
TABLE 4

Smartphone access according to characteristics

\begin{tabular}{l|c}
\hline \multicolumn{2}{c}{ Individual character } \\
\hline Village category \\
\hline Urban & $77.63 \%$ \\
\hline \multicolumn{2}{c}{ Education Level } \\
\hline Uneducated (yet) & $22.37 \%$ \\
\hline Elementary school & $1.32 \%$ \\
\hline Junior High School & $11.84 \%$ \\
\hline High School & $13.16 \%$ \\
\hline bachelor & $51.32 \%$ \\
\hline master / doctorate & $19.74 \%$ \\
\hline \multicolumn{1}{c}{ Family income } & $2.63 \%$ \\
\hline < IDR 1 M & $28.95 \%$ \\
\hline IDR 1 M to 2 M & $18.42 \%$ \\
\hline IDR 2 M to 5 M & $31.58 \%$ \\
\hline IDR 5 M to 10 M & $18.42 \%$ \\
\hline > IDR 10 M & $2.63 \%$ \\
\hline
\end{tabular}

\section{B. Utilization of Smartphones}

The use of smartphone devices is used for any purpose, we can see in Fig. 2. It can be seen that most Smartphone devices are used for communication purposes, then used for information retrieval, then for entertainment and learning, and the least is used for work.

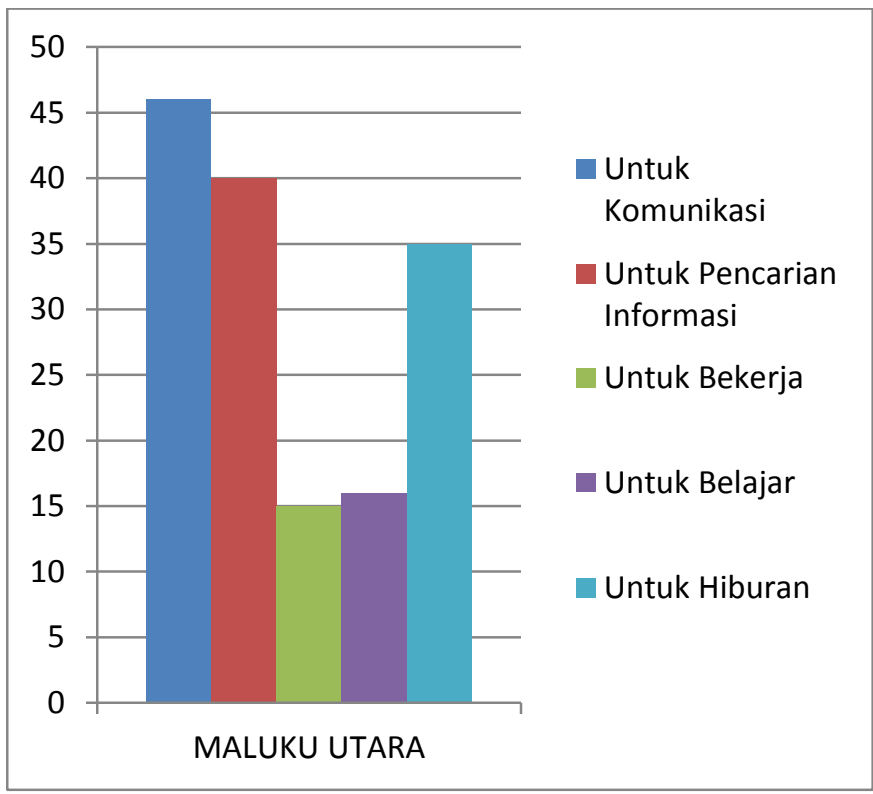

Fig. 2. Utilization of Smartphone 
Some interviews resulted that the smartphone device has not utilized by its features optimally, it is just used as a substitute for the previous mobile phone model whose function is only for communication. It is Very rarely smartphone devices are used by the community for working, this is more due to the type of the community jobs in North Maluku, and especially in rural areas are not related to the features. Most of them are fishermen, a job does not really need many features on smartphones.

\section{Access to Social Media}

The current research also captured information about respondents' access to social media such as Facebook, Twitter, etc. The following table is a graph of social media access based on social media types.

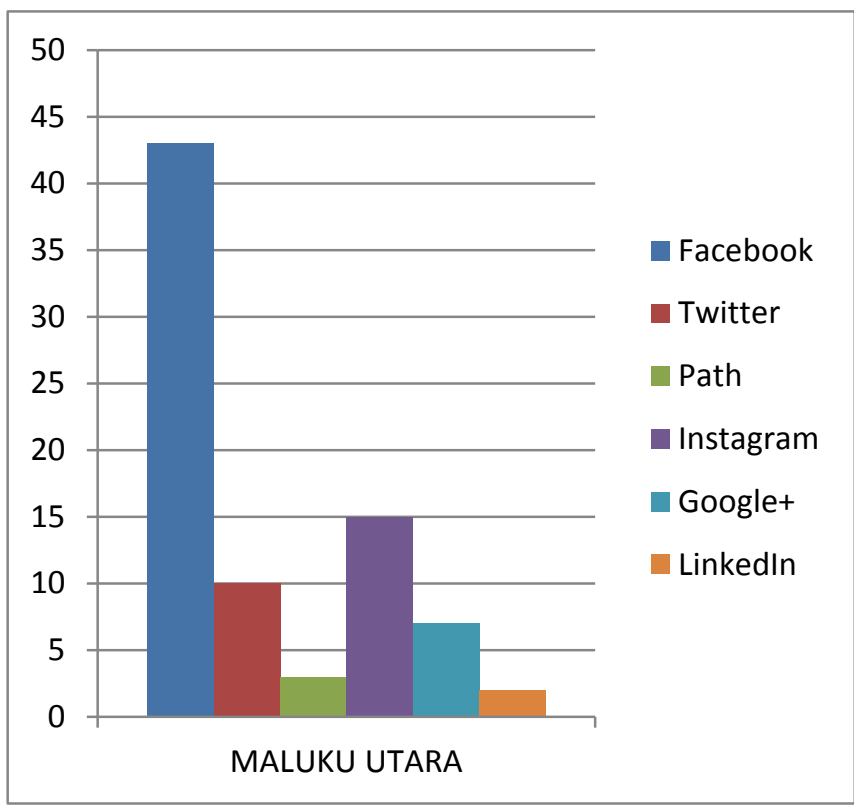

Fig. 3. Access to Social media

As seen from Fig. 3, respondents mostly access Facebook, only then successively Instagram, Twitter, google + , Path and the last is LinkIn. Apart from accessing its use to the types of social media, this study also captured information to find out what topics were of concern to the respondents. There are 6 topics those are used as parameters in this study to see which topics are most frequently discussed on social media, the topics are entertainment, economics/business/trade, humanity, politics, education and employment.

From Fig. 4, we can find out that the topics that are most often of concern on social media in a row are topics of entertainment, education, employment, economics / business / trade and humanity. The topic that gets the least attention is the topic of politics.

Entertainment is a very strong reason in the community to use social media, plus, there is a strong desire to always stay connected to each other in the family friendship community without any distance or time. For a small portion of the community, in addition to entertainment, smartphones are also used for business purposes in seeking additional income, such as selling regional special products or other products.

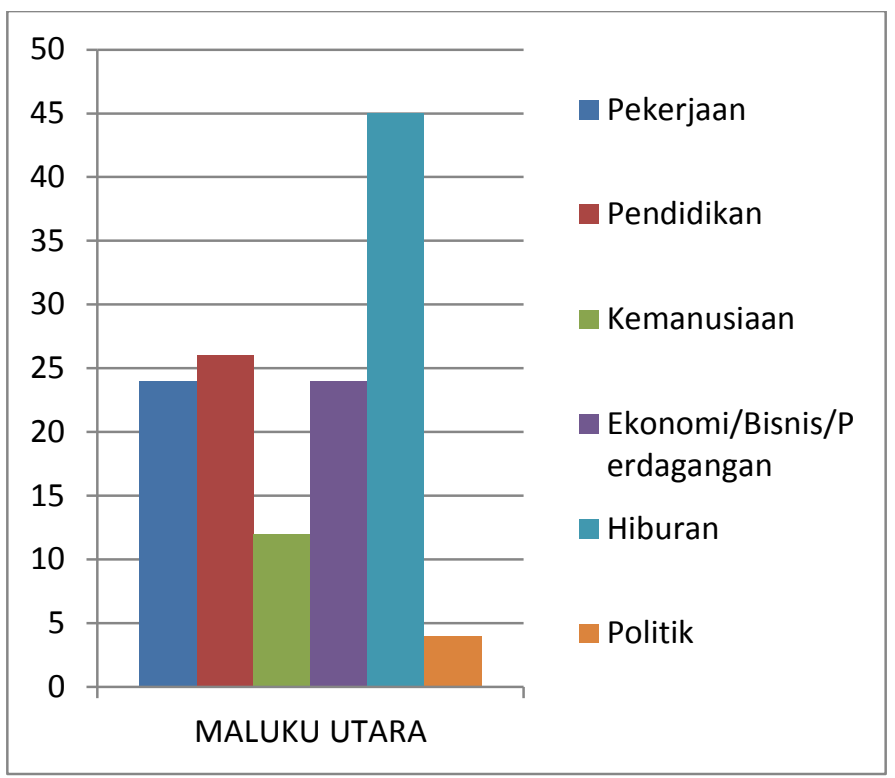

Fig. 4. Topics of concern on social media

Poitic themes on social media are less attractive to social media users, this is due to social media users who are mostly still children to adolescents, those who care less about matters related to politics. Only adult users are interested in political topics

\section{CONCLUSION}

Some things that can be concluded in this study are smartphone technology devices which main purpose is to communicate, have begun to be used for other things such as entertainment and educational support. Of the many social media choices, for the community in North Maluku, Facebook is the most preferred choice.

\section{ACKNOWLEDGMENT}

We would like to thank all those involved in the completion of this research, the Head of the BPSDMP Manado and its staff, the Head of the BBPSDMP Makassar and its staff, the Office of Communication and Information of the North Maluku Province, the people of North Maluku, my researchers friends in Makassar and throughout Indonesia.

\section{REFERENCES}

[1] Badan Litbang SDM-Kemkominfo, "Indikator TIK - Rumah tangga dan Individu," Balitbang SDM, Jakarta, 2016.

[2] C. K. Malecki dan M. K. Demaray, "Social support as a buffer in the relationship between socioeconomic status and academic performance," School Psychology Quarterly Vol 21(4), pp. 375-395, 2006.

[3] S. Alter, "Defining Information Systems as Work Systems:Implications for the IS Field," Business Analytics and Information Systems, no. Paper 22, 2008.

[4] T. d. A. S. Asnawi, "Perubahan Sosial dan Pembangunan," 2014. 
[5] A. K. \&. T. C. Triwahyuni, Pengenalan Teknologi Informasi, Yogyakarta: ANDI, 2003.

[6] D. L. E. M. J. W. Efraim Turban, Information Technology for Management, Transforming Organizations in theDigital Economy, Jhon Wiley and Sons, 2008.

[7] United Nations, United Nations E-Government Survey, United Nations, 2010.

[8] H. H. d. B. Saleh, "Penggunaan Komputer dan Internet di Indonesia," Jurnal Pekomnas Penelitian Komunikasi dan Media Massa Makassar, vol. 12, pp. 15-29, 2009.

[9] Wahyudiyono, "Profil Pengguna Teknologi Informasi dan Komunikasi di Surabaya," KomMTi, vol. 2, pp. 174-197, 2008.

[10] International Telecommunication Union, "Manual for Measuring ICT Access and Uses by Households and Individuals," International Telecommunication Union, Mexico city, 2013. 